is hoped that in the future it may be possible to arrange special training courses for candidates; but at present it is assumed that they will obtain the necessary knowledge and experience in the course of their normal duties. Other than the registration and examination fees, the candidate will not be liable for any other expenses.

\section{Grants for Research in Experimental Psychiatry}

THE Rockefeller Foundation of New York has made a grant of $£ 28,800$ to the Department of Experimental Psychiatry, University of Birmingham, for research in psychiatry, and the biochemistry and pharmacology of the nervous system. . The department was founded in October 1951. Its aim is the application of experimental method to problems of clinical psychiatry. The problems under investigation at present are essentially neurochemical and neuropharmacological. It is, however, hoped to develop systematic studies into the preventive and social aspects of psychiatry as well. An Early Treatment Centre (comprising in-patient, day-patient and outpatient facilities) is being planned, and should, when complete, provide a suitable setting for studies of this kind.

Government Grants for Nuclear Research in Sweden

THE Government of Sweden has announced that it is making grants totalling $\mathrm{Kr} .1,500,000$ (that is, about $£ 100,000$ or 300,000 dollars) to be spent during the budget year of 1953-54 on nuclear research in Sweden. Among the various kinds of research for which the money is intended are included the following : additional grant for the building of a Van de Graaff generator at the University of Lund ; costs for the operation of the high-tension laboratory of the Karolinska Institutet, Stockholm, and for emanation experiments at the same institute; research into the beta- and gamma-radiating elements stored in the human body; synchrotron laboratory experiments and electronics experiments at the Tekniska H.ögskolan in Stockholm; and other aspects of nuclear chemistry and nuclear physics at various institutions,

\section{Chemical Engineering Conference}

THE Institution of Chemical Engineers and the Chemical Engineering Group of the Society of Chemical Industry are organizing a Cbemical Engineering Conference to be held during September 7-11, at Olympia, London, at the time of the Engineering, Marine and Welding Exhibition and the Chemical Plant Exhibition. The Conference will be open to all visitors to the Exhibition. The programme includes papers on carbon and graphite as materials of construction for chemical plant, production and properties of tantalum and zirconium, developments in the production of chlorine with special reference to mercury cells, recent advances in milk processing plant, evaporation with particular reference to heatsensitive liquids, recent advances in distillation, production of formaldehyde from methanol by the silver catalyst process, and application of plastics to chemical plant. There will also be a discussion on British chemical engineering in the light of recently published reports, to be opened by Sir Harold Hartley and Mr. J. Grange Moore.

Seventh Congress of the International Scientific Film Association

THE seventh congress of the International Scientific Film Association will be held during September 18-27 in the National Film Theatre and Royal Festival Hall, London, S.E.1. During this period there will be meetings of the general assembly of the International Scientific Film Association, of the permanent committees dealing with medical, research, technical and industrial films, as well as the usual Festival of Scientific Films. A special committee of the British Scientific Film Association will consider and recommend films for submission to the Festival; full details of films should be sent, including title, runningtime, gauge, date of production, brief synopsis, etc. In addition, the Association would be glad to have de'ails of research and record films of specialized types, which need not necessarily be in the form of complete titled 'films', for showing at meetings of the permanent committees dealing with medical, research, technical and industrial films. Special meetings and film shows will be devoted to the technique and application of films in medicine; further particulars may be obtained from the vice-chairman of the Medical Committee, Dr. R. C. MacKeith, Guy's Hospital, London, S.E.1. Information about the Congress as a whole can be obtained from the General Secretary, Scientific Film Association, 164 Shaftesbury Avenue, London, W.C.2.

\section{Science and Applications of Photography}

AN international conference on the "Science and Applications of Photography" is being organized by the Royal Photographic Society of Great Britain and will be held at the Institute of Education (London University), Malet Street, London, W.C.1, during September 19-25. The provisional programme includes public lectures by Dr. C. E. Kenneth Mees and by Dr. R. M. Evans, Color Control Division, Eastman Kodak Company, both to be delivered at the Royal Institution, Albemarle Street, London, W.1, and five sessions of sections for the presentation of papers and for discussion. Membership of the Conference is open to all ; the fees are, for members of the Society and lecturers $\mathfrak{E l} \mathbf{l} s$, , and for nonmembers $£ 22 s$. This includes one set of preprints of the papers presented in any one of the five sections of the Conference; preprints of papers in other sections can be obtained on payment of an additional 5s. for each section. The full text of the papers will also be available in microfilm or similar form. Further particulars can be obtained from the Secretary of the Royal Photographic Society, 16 Princes Gate, London, S.W.7. The annual congress of the International Scientific Film Association is being held in London during approximately the same period, and reciprocal arrangements are being made to enable members of each to participate in the activities of the other, without additional fees.

\section{Third International Congress of Electroencephalo-} graphy and Clinical Neurophysiology

TнE Third International Congress of Electroencephalography and Clinical Neurophysiology will be held in Boston at Agassiz House, Radeliffe College, Cambridge, Mass., during August 16-21. Besides the scientific sessions there will be six symposia on, respectively : recent developments in electroencephalographic techniques; the physiological basis of the encephalogram ; the interpretation of the encephalogram; evaluation of activation of the electroencephalogram ; interrelationships between cortex and sub-cortical structures; and characteristics and significance of seizure discharges. Further information regarding the Congress can be obtained 